\title{
Digital Racism: A New Form of Racism, A Threat to the Integrity of the Nation
}

\author{
Pipi Karmila ${ }^{1, *}$, Dasim Budimansyah ${ }^{2}$
}

\author{
${ }^{1,2}$ Universitas Pendidikan Indonesia, Bandung, Indonesia \\ *Corresponding author,Email: pipikar17@upi.edu
}

\begin{abstract}
Media transformation and interaction through digital space born in the circle of globalization, encourage Indonesians to become a digital society by relying on their interactions through cyberspace. Advances in information and communication technology provide convenience in people's lives. However, it has penetrated the lifestyle and social behavior of people who ignore multicultural values. The development of information and communication technology today makes social media an open space for hate speech to beginning to acts of racism in virtual space. This study aims to identify forms of racism on social media in Indonesia. Researchers used a qualitative approach with the phenomenology method. The study found that, First, acts of racism are rife on social media through various digital platforms such as Facebook, Instagram, Twitter, Tik Tok, and YouTube; second, the form of digital racism is demonstrated by digital content in the form of writings, memes, videos, and expressions directly in live chat applications; and thirdly, various racism on social media are contrary to the values of Pancasila and Undang Undang Dasar 1945. Based on this, it is concluded that digital content that contains hate speech, demeans others based on physical characteristics, and shows the superiority of a particular race becomes a source of conflict for multiethnic Indonesian society. Therefore, digital racism as a new form of racism in Indonesian society is part of a major threat to the integrity of Negara Kesatuan Republik Indonesia.
\end{abstract}

Keywords: Digital Racism, Negara Kesatuan Republik Indonesia, Social Media.

\section{INTRODUCTION}

The shift in behavior patterns of traditional society into a digital society is becoming an increasingly interesting topic to discuss. The trend of digitization in various areas of life is the main characteristic of the shift towards the virtual world. Patel, Patel, and Scholar mentions this term known as the Internet of Things (IoT)[1]. Globalization with the transformation of technology, information and communication, encourages Indonesians to become digital citizens who use the internet regularly and effectively in social life. ICT progress provides convenience in people's lives. However, it has penetrated the lifestyle and social behavior of people who increasingly ignore multicultural values. First, Digital Civility Index (DCI) report issued by Microsoft's 2021 shows three main risks in the digital space experienced by Indonesia, including hoaxes and scams, hate speech, and discrimination. Microsoft's report on Digital Civility Index (DCI) throughout 2020 Indonesia was ranked 29th out of 32 country [2]. It means that the politeness level of Indonesian netizens in the media is very low. Even in the Southeast Asian region, Indonesia is the country with the lowest level of politeness in the digital world. Various actions of
Indonesian netizens who tend to be negative lately, contrary to the polite and courteous character of the Indonesian nation. It shows that social media becomes an open space for various moral violations such as racism.

Second, the development of information and communication technology today has given rise to various acts of violation of the value of Pancasila through various forms of media such as Facebook, Twitter, Tik Tok, etc. Third, the current rise of digital racism has become a concern that disrupts the social system of Indonesian society and endangers national integrity.

The rise of racist on social media reminds us that the problem of racism is a real threat to Indonesian unity. Digital transformation is driving new ways of racist in society. Digital media became a means for social movements to achieve their desired goals as a result of globalization which eliminates distance between mankind. Globalization in the study of Citizenship Education puts citizens in the openness of information that marks the beginning of digital citizenship[3][4]. Racism has long been a source of horizontal conflict in the life of Indonesia's multicultural society. Digital racism, as one of the negative actions on social media, is 
a denial of the ideology of Pancasila and Bhineka Tunggal Ika. So it becomes a big question: how is the form of digital racism that is rife on social media in Indonesia?

This research is a study of citizenship education in the socio-cultural field that focuses on various forms of racist on social media in Indonesia. This study will reveal various forms of racist on social media in Indonesia, which will affect the social capital of the community and become a threat to the integrity of the Nation of Indonesia.

\section{THEORETICAL REVIEW}

\subsection{Digital Racism}

Race is a socio-political construct involving complex social and historical processes. In historical reviews, racial issues in America are the most highlighted. The issue of racists has been developing since 1936, and in 1907 the concept of racialism and racialism emerged. People who study racial differences can be called racialists, then someone is considered racist when they are white and doesn't apply to black people. M. J. Maher describes racism as a belief or practice that assumes inherent and significant differences between human beings [5]. A person is considered racist when demeaning, indifferent, hurting others based on racial differences. Indonesia as a multi-ethnic country, has a long history with a past heritage on the issue of race. Racism in the course of indonesian history became a way for colonial colonists to subdued Indonesia. The conquest of the Indonesian nation began with the conquest of the most substantial dimension of its race.

The term race based on differences in physical characteristics became a strategy in the colonization and conquest of a group. Maguire, et al. describe that race is also used when discussing discrimination and prejudice. In this regard, race is narrowly defined and applied as racism[6]. Woods states the term race which refers to differences in physical characteristics, determines the different characteristics and traits of humans, and various racial differences result in the superiority of a particular race. This beginning to the terms race and racism. It is concluded that race is a term that indicates differences in human traits and characteristics that are genetically derived from generation to generation, while racism is a term used in racial issues that indicates the superiority of a particular race that gives rise to the attitude of discriminating or demeaning certain groups and being a source of conflict in society.

Social media platforms allow users to engage in hatred channeled through digital media. This pushes colonial racism back into the picture, allowing digital platforms easier expression and wider racist reach. Nakamura in 2013 concluded that the technological imagination captures and mobilizes racial strerotifs[7]. Beside that, Sonu Bedi explains that digital racism is a racial injustice that occurs in digital space[8]. It can be concluded that digital racism is a social act that shows a difference by demeaning, indifferent, significantly hurting others regarding physical characteristics that are carried out directly through digital media in virtual life.

\subsection{Media Social}

Social interaction through new media is becoming a major attraction for today's society. New media was born as a result of the media revolution with the main goal of providing convenience in large-scale interactions, this is characterized by the development of digital and cellular technology. Various types of new media are becoming part of the development of digital and mobile technology around the world, including social media as a form of new media involving the participation of its users. Jimmie Manning explains that media development is divided into two different ages, namely the era of broadcast and the interactive era[9]. The era of broadcast exclusively concentrates media through one entity such as radio and television. Through one production, the message delivered by broadcast media is distributed to many people. But feedback from listeners and audiences is often indirect, delayed and impersonal. Interactive era is communication mediated between smaller individuals usually between families. However, the beginning of new media with the development of digital and cellular technology opens wider interaction with interactivity as its main function.

Social media is becoming a major need in global community interaction. Kaplan and Haenlien explained that social media is generally defined as a group of internet-based applications built on ideological basis and web 2.0 technology, enabling the creation and exchange of content created by users[10]. Social media became a virtual meeting room of the global community without limited distance and time, which became an obstacle in traditional technology. Less than a decade was born a variety of social media with diverse types and benefits. Kaplan and Haenlien (2010) made a classification of social media based on the presence of social / media wealth and self-presentation / self-disclosure, described as follows:

1. Collaborative projects enable shared and concurrent content creation by multiple users. That means allowing the manifestation of the most democratic user-generated content. One example is Wikipedia, a website that allows users to add, remove, and modify text-based content. The main idea in collaborative projects in the efforts that many actors do together will lead to better outcomes, rather than results that can be achieved individually.

2. Blog as one of the earliest forms of social media. Blogs are a special type of website that usually contains personal things that describe the life of the author. Blogs are usually privately managed but allow interaction through the addition of comments provided by visitors to the blog.

3. Content communities, different content communities on the internet have different types of media. The 
content community has the primary goal of sharing media content with its users. Types of content media that are rampant on social media such as text-based media type BookCrossing, photos such as Flickr, videos such as Youtube, power point presentations such as Slideshare.

4. Social networking sites, is an application that allows users to connect privately with accounts that contain personal information. The social networking app allows users to invite each other into friends and colleagues to have access to the user's personal profile. The user's personal profile contains various types of information such as photos, videos, audio and blog files. Social networking sites allow users to view each other's profiles without being able to change other people's personal data. Furthermore, social networking sites are created to facilitate personal communication between its users. Examples of social networks are Facebook, Twitter, Instagram, Line, WhatsApp

5. Virtual world games, virtual worlds become a platform that replicates a three-dimensional environment where users can appear in the form of personalized avatars and interact with each other as they do in the real world. In this sense cyberspace is the main embodiment of social media. Because it provides the highest level of social presence and media wealth of all the applications that have been discussed. The first virtual game world, which allows its users to behave according to the rules in the context of online games with many players[11].

\section{METHOD}

The researchers will explore digital racism in Indonesia, where the orientation of the study is to focus on discovering forms of racism on social media. The researchers used a qualitative approach with phenomenological methods. The research aims to explore intensive forms of racism on social media in Indonesia. Through texts and discourses that explain individual experiences related to digital racism. In this study, subjects were selected based on specific "purposive" goals or considerations. subjects of this research must be able to explain this form of digital racism consciously and straightforwardly. The location of the study does not lead to one place, because this research is an exploration activity of social media, this research is conducted in a digital space involving digital actors and experts as experts and observers who can provide clear information about the form of racism on social media.

Therefore, the data collection technique used is discourse analysis or literature analysis as a form of observation and documentation studies, then strengthened by interviews. As Burrows explains (2017) the method of analysis of literature is used because it involves understanding the language, symbols, and images contained in it to obtain information about how people understand and communicate life. Visual, written, or oral messages provide instructions on an understandable way of communication. Qualitative data analysis in this study focuses on Miles and Huberman's data analysis process which includes data reduction, data display, and conclusion withdrawal.

\section{RESULT AND DISCUSSION}

Indonesian society sociologically and demographically is a compound society with the main characteristics of the diversity of culture, language, religion, race, and ethnicity. diversity that the Indonesian nation has is like two sides of the currency. Being a characteristic and strength for the Indonesian nation, but then becoming a source of all opposition in the life of the nation. Horizontal conflicts between tribes and religions are endless, and the rise of racist reminds us that the problem of racism is a real threat to Indonesian unity. The modern era with the rapid development of information and communication technology, provides convenience for Indonesians to engage in the global world through virtual space. Interactions between each other that tend to be direct, traditional and limited, turn into digital interactions with new media. The concept of new media was developed by Pierre Levy (2001), a new media is an idea of the development of media. Pierre levy distinguishes two types of virtual reality, the first limited virtual world such as CD-ROOM and installation made in an off-line form. Second, virtual reality is open (online). So it is possible to be accessed by everyone and interaction can be done very quickly (information superhighway)[13]. New media opens up the widest space for Indonesians to interact actively in the digital space. It was reinforced by Manning (2014) that the beginning of new media such as social media, opened up wider and interactive interactions in the community[9]. The feedback provided is not impersonal, but interactivity as the main function of new media can be implemented.

The various facilities offered by new media also have a variety of negative impacts for multicultural societies such as Indonesia. Social media is the easiest-to-use digital space, being an open space for racial injustice in the digital space. Various practices of injustice that assume differences between people, as M.J Maher explained that a person is considered racist when he demeans, indifferently, is hurting others based on significant differences in physical characteristics (race) [5]. Various racism on social media in Indonesia are increasingly rampant. This is evidenced by the Form of racism on social media in Indonesia, based on discourse analysis: 


\begin{tabular}{|c|c|}
\hline $\begin{array}{l}\text { Classification of social media } \\
\text { based on social presence / } \\
\text { media wealth and self- } \\
\text { presentation / self-disclosure }\end{array}$ & Forms of Racist \\
\hline \multicolumn{2}{|l|}{ a. Social networks } \\
\hline Facebook & $\begin{array}{l}\text { - Humiliation status } \\
\text { - Hate speech } \\
\text { - Racist comments } \\
\text { - Racist memes } \\
\end{array}$ \\
\hline Twitter & $\begin{array}{l}\text { - Humilation status } \\
\text { - Hate speech } \\
\text { - Racist comments } \\
\text { - Racist memes }\end{array}$ \\
\hline Instagram & $\begin{array}{l}\text { - Racist comments } \\
\text { - Threat }\end{array}$ \\
\hline Tik Tok & $\begin{array}{l}\text { - Racist video content } \\
\text { - Racist comments } \\
\text { - Hate speech }\end{array}$ \\
\hline \multicolumn{2}{|l|}{ b. Content community } \\
\hline DouTube & $\begin{array}{l}\text { - Racist comments } \\
\text { - Hate speech }\end{array}$ \\
\hline
\end{tabular}

Figure 1. Form of racist on social media in Indonesia

Based on the table, that social networks and content communities as a classification of social media contain a variety of racism. The social media classification chosen is the most frequently used social media based on the results of Asosiasi Pengguna Jasa Internet Indonesia survey in 2019-2020 which is classified as a social network and content community[15]. Strengthened by Kaplan and Haenlien (2010), social networks are included in the social media classification based on social presence at the medium level with high selfpresentation[10]. While the content community is a social media with a social presence / media wealth that is at the medium level, with low self-presentation. Even though being at the medium level of self-presentation Facebook is the most used social networking app, with monthly active users reaching 2.7 Billion as of January 2021 based on We are Social (2021) data. One example of a racist status belongs to the Facebook account of Ambroncius Nababan, to Natalius Pigai. then racist comments on the Instagram account Patrich Wanggai, Indonesia National Athlete from Papua. It clarifies that racism on social media can be text messages, images, comments, and videos that are then referred to as cyber racism. Reinforced by the Australian Human Right Commission (2014) that cyber racism is racism that occurs in cyberspace that contains racist comments, images, videos, posts or text messages through social networking sites[16]. These actions are a denial of Pancasila and Law Number 40 of 2008 on the Elimination of RACIAL and ethnic Discrimination Measures.

The development of technology for multicultural societies such as Indonesia provides opportunities to strengthen the nation's national integrase, but also a threat to the unity and unity of the nation. The beginning of technology strengthens the social interaction of society, but then provides an open space for injustice. Reinforced by Daniel's research in 2013, by identifying social media, particularly social networking platforms, as places where race and racism play attractively and with a lot of courage[17]. This suggests that social media shapes the racist dynamic through media affordability as a virtual space. Social media has been shown to revive racism and give it a new form of negative action domestically as well as across state boundaries.

The racial injustice shown by some social media accounts in Indonesia has resulted in a variety of responses, clashes and riots in the community. Various cases of racial sentiment in Indonesia are most common in Chinese and Papu ethnics. Nowadays, various injustices on social media as a phenomenon are also influenced by the pandemic condition covid 19, for example the spread of fake news, which increases sentiment towards Chinese ethnic. The racism phenomena that occur in Indonesia, with the support of technology today are not quite seen as a regular phenomenon that is momentary. But it must be seen more critically, that there are systematic efforts from certain interest groups that begin to utilize the digital world and pandemic emergency situations to build a more sentimental mindset so that the social, economic, political, defense and security situations of our nation become distrubed.

The phenomenon of digital racism in Indonesia is considered to be a threat to this nation. a variety of digital content with racist, hate speech, demeaning others, comparing the advantages between races, which in practice is done through digital media. Demonstrate acts of threats, psychological, social, and physical intimidation directed at individuals and groups. Therefore, digital racism as a new form of racism in Indonesian society is part of a major threat to the integrity of Negara Kesatuan Republik Indonesia that must be taken seriously. Clearly bringing digital racism in the form of cyber racism is an act that is contrary to the common consignment of Indonesian society, namely Pancasila, and can soften the national integration in society. Where degrading actions between races will impede the birth of dual loyalty as a condition of national integration. Van den Bergh reinforced that the two main factors that allow the birth of integrase in a compound society is the existence of a consensus or mutual agreement among most of the community on the value of fundamental societal values. Then, there are various societies from various social unions (cross cutting affiliations) that are the beginning to cross cutting loyalities[18].

From the various explanations, it is clear that the rise of digital racism will interfere with the efforts of Citizenship Education to foster the value of Indonesian unity. Therefore, citizenship education is a systematic effort in building good citizens. As well as an effort to cultivate the values of Pancasila as the basis of Indonesian unity. It needs to be strengthened by the content of digital citizenship and digital literacy in the curriculum in schools and universities. Digital citizenship content that is rooted in concern for digital ethics, as the norm in the use of technology based on Pancasila should be a systemic part to equip Indonesian society as a digital society. As Ribble and Miller asserted that Digital citizenship is rooted in concern for digital 
ethics, as the norm of behavior relating to the use of technology, this interpretasi was chosen because it is a prominent part of Education[19]. Citizenship education focuses on strengthening the digital ethics of citizens, referring to the development of aspects of digital society, including the personal environment and Education. Three dimensions of digital citizenship developed by Ribbe and Miller, namely 1) respect yourself / respect others, 2) educate themselves / connect with others, and 3) protect themselves / protect others, in line with the values of Pancasila as a joint constituency in building national integrase. So that it can be used to equip Indonesians with digital literacy as knowledge and proficiency towards the wise use of technology in the face of current and future technological attack.

\section{CONCLUSION}

Racism is an endless problem in Indonesia. One source of horizontal conflict is currently supported by the birth of new media. Make digital space an open space for racist acts. Digital racism is a phenomenon of racial injustice that occurs in the digital space. Born with various forms of text messages, images, comments, and videos that came to be referred to as cyber racism. Digital content that contains hate speech, demeans others, compares the advantages between races, which in practice is done through digital media. Exhibit acts of threat, psychological, social, and physical intimidation aimed at individuals and groups. Digital media is shaping the racist dynamic through the affordability of media as a virtual space. Therefore, it is very concerning that racism on social media is a serious threat to the integrity of the Indonesian nation. Citizenship education, as a systematic effort to build intelligent citizens, should be strengthened by digital citizenship content and digital literacy in the curriculum in schools and universities. Digital citizenship content is rooted in digital ethical concerns in line with the Indonesian principles of Pancasila society. Therefore, digital citizenship and digital literacy as the norm in the use of Pancasila-based technology must be a systemic part to equip Indonesian society as a digital society. In this regard, it is necessary to develop a national anti-racism strategy through several steps, including 1) creating awareness of racist acts and their effects on individuals and society; 2) develop good examples for countering racist acts; 3 ) Provide access to information about racism in its entirety, so that the public knows how to access legal protection against acts of racism in Indonesia.

\section{ACKNOWLEDGMENT}

We extend our sincere to The Third Annual Civic Education Conference commite as a reviewer for this article

\section{REFERENCES}

[1] K. K. Patel, S. M. Patel, and P. G. Scholar, "Internet of Things-IOT: Definition, Characteristics, Architecture, Enabling Technologies, Application \&amp; Future Challenges," Int. J. Eng. Sci. Comput., vol. 6, no. 5, pp. 1-10, 2016, doi: 10.4010/2016.1482.

[2] "Digital-Civility-2021-Global-Report." .

[3] P. N. Howard and M. M. Hussain, "The role of digital media," J. Democr., vol. 22, no. 3, pp. 35-48, 2011, doi: 10.1353/jod.2011.0041.

[4] F. Rahmandani, "Strategi guru pkn dalam penguatan literasi digital peserta didik guna membentuk karakter kewarganegaraan digital,” no. January, 2020.

[5] Y. Humaira, "Rasisme Dalam Film Agathe Clèry Makalah Non-Seminar," 2014.

[6] G. S. A. Renggi, "Dinamika Kekerasan Etnis Di Yogyakarta Dan Dampak Sosio-Psikologisnya Pada Mahasiswa- Mahasiwa Yang Berasal Dari Indonesia Timur," 2014, [Online]. Available: https://repository.usd.ac.id/4241/2/109114142_full .pdf.

[7] E. Siapera and P. Viejo-Otero, "Governing Hate: Facebook and Digital Racism," Telev. New Media, vol. 22, no. 2, pp. 112-130, 2021, doi: $10.1177 / 1527476420982232$.

[8] S. Bedi, Digital Racism. In Private Racism, Cambridge: Cambridge University Press, 2019.pp 82-112.

[9] K. Harvey, "Social Media, Definition and Classes of," Encycl. Soc. Media Polit., no. January, 2014, doi: 10.4135/9781452244723.n485.

[10] A. M. Kaplan and M. Haenlein, "Users of the world, unite! The challenges and opportunities of Social Media," Bus. Horiz., vol. 53, no. 1, pp. 59-68, 2010, doi: 10.1016/j.bushor.2009.09.003.

[11] A. Kaplan and M. Haenlein, "ScienceDirect Collaborative projects ( social media application ): About Wikipedia , the free encyclopedia," Bus. Horiz., vol. 57, no. 5, pp. 617-626, 2017, doi: 10.1016/j.bushor.2014.05.004.

[12] J. Burrows, "Textual Analysis," A Companion to Digit. Humanit., pp. 323-347, 2017, doi: 10.1002/9780470999875.ch23.

[13] B. Dar, J. Olusegun, and D. Ph, “AFRREV IJAH An International Journal of Arts and Humanities ISSN : 2225-8590 ( Print ) ISSN 2227-5452 ( Online ) Nigeria Prisons and the Dispensation of Justice," vol. 1, no. 3, pp. 208-233, 2012.

[14] A. Vromen, "Digital Citizenship and Political Engagement," Digit. Citizsh. Polit. Engagem., pp. 225-237, 2017, doi: 10.1057/978-1-137-48865-7.

[15] Asosiasi Penyelenggara Jasa Internet Indonesia, 
“Laporan Survei Internet APJII 2019 - 2020," Asos. Penyelenggara Jasa Internet Indones., vol. 2020, pp. 1-146, 2020, [Online]. Available: https://apjii.or.id/survei.

[16] R. Charlina, “Analisis Komparatif terhadap Implementasi Protokol Tambahan," vol. 3, no. Cets 189, pp. 39-47, 2017.

[17] J. Daniels, "Race and racism in Internet Studies: A review and critique," New Media Soc., vol. 15, no. 5, pp. 695-719, 2013, doi: $10.1177 / 1461444812462849$.

[18] P. Suparlan, "Masyarakat Majemuk dan Perawatannya," Antropol. Indones., vol. 0, no. 63, pp. 42-50, 2014, doi: 10.7454/ai.v0i63.3397.

[19] M. Ribble and T. N. Miller, "Educational leadership in an online world: Connecting students to technology responsibly, safely, and ethically," J. Asynchronous Learn. Netw., vol. 17, no. 1, pp. 137-145, 2013, doi: 10.24059/olj.v17i1.310. 